\title{
Cerkiew prawosławna na Podlasiu do końca XVI wieku
}

\author{
ks. Piotr Kiryluk \\ Katolicki Uniwersytet Lubelski \\ Polska \\ ORCID: 0000-0001-7491-6976 \\ piotrkiryluk@op.pl
}

P. Kiryluk, The Orthodox Church in Podlasie until the end of the 16th century, Elpis, 21 2019: 41-50.

\begin{abstract}
The article presents the outline of the history of Orthodox Church In the region of Podlasie until the end of 16-th century. The jurisdiction of Podlasie orthodox parishes, their founders and the number of churches were being analysed.
\end{abstract}

Streszczenie: Artykuł przedstawia zarys historii Cerkwi Prawosławnej na terenach Podlasia do końca XVI wieku. Przeanalizowano przynależność jurysdykcyjną podlaskich prawosławnych parafii, założycieli oraz liczebność cerkwi.

Keywords: The Orthodox Church, Podlasie Region, parish, foundation of the church

Słowa kluczowe: Cerkiew prawosławna, Podlasie, parafia, założenie cerkwi

\section{Cerkiew prawosławna na Podlasiu do końca XVI wieku}

Ziemie Podlasia nie stanowiły osobnej struktury organizacyjnej Kościoła prawosławnego. Prawdopodobnie pierwotnie cerkwie podlaskie podlegały jurysdykcyjnie biskupom turowsko-pińskim (Jabłonowski, 1909, s. 227; Sosna, 1978, s. 64). W XIII w. większość ziemi podlaskiej weszła w skład Księstwa Halicko-Wołyńskiego i znalazła się pod zwierzchnictwem biskupów włodzimierskich. Zależność od książąt ruskich południowych obszarów ziem podlaskich wywarła istotny wpływ na dzieje $\mathrm{i}$ charakter Cerkwi prawosławnej nad Bugiem i Narwią. Z okresu panowania książąt halicko-wołyńskich pochodzą najstarsze wzmianki o dziejach cerkwi podlaskiej. Latopis ipatiewski wspomina pod rokiem 1260 o cerkwi Narodzenia Najświętszej Marii Panny w Mielniku (Bobowski,1863,s.978)'. Siedem lat wcześniej książę halicki Daniel koronował się w cerkwi Bogurodzicy w Drohiczynie. Jego śmierć w 1264 roku spowodowała upadek Księstwa Halicko-Wołyńskiego i wzrost potęgi Litwy, która za rządów Giedymina (13151341) i Olgierda (1344-1377) wchłonęła ziemię podlaską. W granicach Wielkiego Księstwa Litewskiego ostatecznie ukształtowana została struktura organizacyjna Kościoła prawosławnego.

\footnotetext{
Według latopisu książę Daniel, ulegając władzy chana tatarskiego Burunaja, wysłał ks. Wasylka na podbój Litwy. „Jechał Wasilko za brata i prowodi jego do Berestia, i posła snim swoja ludi, i pomolisia Bogu swiatomu Spasu Izbawniku, jaże jest ikona w gorodie Mielnicy w cerkwi św. Bogorodzicy, nynie stoit w wiełice czesti i obieszczasia Daniło korol ukrasiti ju".
}

Po upadku Wielkiego Księstwa Kijowskiego, spowodowanego rozdrobnieniem feudalnym i najazdem mongolskim w 1240 roku, coraz częściej metropolici kijowscy przebywali nie w stolicy metropolii - Kijowie, a Włodzimierzu Suzdalskim. Około 1300 roku metropolita Maksym (1283-1305) przeniósł się tam na stałe. Fakt ten wywołał poważne następstwa w dziejach Kościoła prawosławnego na ziemiach Wielkiego Księstwa Litewskiego. Metropolici kijowscy aktywnie uczestniczyli w procesie zjednoczenia ziem ruskich, przyczyniając się do wzrostu prestiżu księstwa włodzimierskiego, a następnie moskiewskiego. Działalność ich wywołała obawy władców litewskich o trwałość przynależności podbitych ziem ruskich do Litwy, Podobnie znaczna część książąt ruskich nie chciała być podporządkowana nowemu politycznemu ośrodkowi leżącemu poza granicami kraju. Książę włodzimiersko-halicki Jerzy I, dążąc do usamodzielnienia się Kościoła prawosławnego, znajdującego się w granicach jego państwa, od metropolitów kijowskich, wystarał się w 1303 roku u patriarchy konstantynopolitańskiego zezwolenie na ustanowienie metropolii halickiej (Chodynicki, 1934, s. 3). W jej skład weszły diecezje: włodzimierska, halicka, przemyska, łucka, turowska i chełmska. Powstanie nowej metropolii uszczupliło rangę i znaczenie dotychczasowej organizacji cerkiewnej, dlatego metropolici kijowscy podjęli działania o jej zniesienie. Wskutek zabiegów dyplomatycznych i rozprzężenia powstałego na Rusi Halickiej po śmierci ostatniego księcia halicko-wołyńskiego z dynastii Rurykowiczów w 1324 roku metropolia halicka upadła. Reaktywowana na nowo dzięki staraniom gorliwego wyznawcy prawosławia, księcia włodzimierskiego Lubarta - Dymitra 
Giedymowicza w 1331 roku ponownie zostaje zniesiona w 1347 roku, w wyniku działań metropolity kijowskiego Seognasta (1328-1353) i wielkiego księcia Moskiewskiego Szymona Dumnego (1340-1353).

Z tych samych względów jak na Rusi Halickiej na przełomie XIII i XIV w., powstaje na podbitych przez Litwę ziemiach ruskich drugi ośrodek władzy cerkiewnej w Nowogródku. Wielki książę litewski Olgierd (13451377), podporządkowując sobie coraz to większe tereny zamieszkałe przez Rusinów, czynił starania o utworzenie dla nich metropolii litewskiej. Zabiegi książąt litewskich nieoczekiwanie zyskały poparcie $\mathrm{w}$ patriarchacie carogrodzkim, zainteresowanym rozszerzeniem wpływów Kościoła prawosławnego na Litwie. Jednocześnie patriarcha Kalist w 1354 roku zatwierdził w godności metropolity władykę Aleksego w Moskwie (1354-1378), tym samym akceptując przeniesienie stolicy metropolii z Kijowa do Włodzimierza z zachowaniem dotychczasowej tytulatury. W tym też roku patriarcha uznał kandydata księcia Olgierda na metropolię kijowską - Romana. Decyzja patriarsza doprowadziła do podziału metropolii kijowskiej na dwie części. Roman otrzymał tytuł metropolity Litwy i władzę na Zachodniej Rusi bez Kijowa z władyctwami: litewskim, połockim i turowskim. Aleksy zaś otrzymał tytuł metropolity kijowskiego i całej Rusi oraz władzę nad Cerkwią Rusi Większej. Przyłączenie Kijowa do Wielkiego Księstwa Litewskiego zdopingowało starania książąt litewskich do uzyskania całkowitej niezależności Kościoła prawosławnego na Litwie od Moskwy. Pojawiły się nawet tendencje do podporządkowania tej ostatniej własnym wpływom. Z drugiej strony książęta moskiewscy i metropolici kijowscy nie zrezygnowali ze starań o odzyskanie wpływów na całej Rusi. W 1375 roku wskutek zabiegów Olgierda metropolitą kijowskim zostaje wybrany władyka Cyprian, który po śmierci metropolity Aleksego (rezydującego w Moskwie) doprowadza do zjednoczenia metropolii kijowskiej (moskiewskiej) i litewskiej (kijowskiej). Ażeby utrzymać jedność organizacji cerkiewnej, metropolita Cyprian zmuszony był w 1381 roku przenieść swoją rezydencję do Moskwy. Starania metropolity Cypriana o zachowanie jedności Cerkwi nie były na tyle skuteczne, aby przezwyciężyć różnice polityczne i aspiracje władców obu państw. Śmierć Cypriana spowodowała ponowny podział administracyjny Kościoła prawosławnego na Rusi. W 1406 roku w Moskwie metropolitą zostaje wybrany władyka Focjusz, a na Litwie w dziewięć lat później Grzegorz Camblak. Przez wybór metropolity Camblaka na synodzie w Nowogródku 15 listopada 1415 roku zostały uformowane podstawy organizacji Kościoła prawosławnego w Wielkim Księstwie Litewskim. Na jego czele stał metropolita kijowski, rezydujący w Kijowie bądź Nowogródku. Do metropolii kijowskiej należały: arcybiskupstwo połockie oraz biskupstwa: czernihowskie, łuckie, włodzimierskie, przemyskie, smoleńskie, turowskie i chełmskie. Na wspomnianym synodzie nowogródzkim metropolia halicka została włączona jako osobna diecezja do metropolii kijowskiej. Mimo że obie metropolie znajdowały się w dwóch oddzielnych krajach
(Wielkie Księstwo Moskiewskie i W. Ks. Lit.), to formalny podział między nimi, wzdłuż granic państwowych, nastąpił w 1458 roku. Zmieniła się wówczas tytulatura rezydujących w Moskwie metropolitów - z kijowskich na moskiewskich. Zwierzchnicy Kościoła prawosławnego na terenie W. Ks. Lit. uzyskali tytuł „metropolitów kijowskich, halickich i całej Rusi” (Makary, 1879, s. 63 - 68; 166-177, 334-335, 493-502, 516-519; Hruszewskyj, 1907, s. 459-460; Chodynicki, 1934; Bieńkowski, 1969, s. 788-789).

$\mathrm{Z}$ dziesięciu diecezji wchodzących w skład metropolii kijowskiej po jej ostatecznym uformowaniu się w 1458 roku, siedem znajdowało się w granicach W. Ks. Lit. (kijowska, połocka, smoleńska, czernihowska (brańska), turowsko-pińska, łucka i włodzimierska), a trzy w obrębie ziem ruskich Korony (chełmska, przemyska i halicka). W 1500 roku w wyniku wojny z Wielkim Księstwem Moskiewskim Litwa utraciła na rzecz Moskwy ziemię czernihowską z biskupstwem czernihowskim, a w 1514 roku eparchię smoleńską. W ten sam sposób w 1563 roku odpadło od metropolii kijowskiej władyctwo połockie, które po zdobyciu w 1579 roku Połocka przez Stefana Batorego ponownie znalazło się w granicach W. Ks. Lit. i metropolii (Pokrowskij, 1897, s. 389). Do 1596 roku nie nastąpiły istotne zmiany w organizacji metropolii kijowskiej. Składała się ona w II połowie XVI wieku z diecezji: kijowskiej, włodzimiersko-brzeskiej (ordynariusz jej był nominalnie uważany za następcę metropolity - „prototronos”), lucko -ostrogskiej, połocko-witebskiej (z godnością arcybiskupa), przemysko-samborskiej, chełmskiej, halickiej i lwowsko-kamienieckiej.

Ziemia podlaska, która weszła w skład Wielkiego Księstwa Litewskiego, jurysdykcyjnie została podporządkowana biskupom włodzimierskim i kijowskim. Przedstawienie granic obu diecezji wymaga szczegółowej analizy przynależności jurysdykcyjnej poszczególnych parafii. Bardziej szczegółowe informacje o granicach diecezjalnych posiadamy dopiero $z$ II poł. XVIII wieku i to głównie dla biskupstw unickich. Dane te nie mogą stanowić podstawy do rekonstrukcji struktury terytorialnej poszczególnych władyctw w XVI wieku. Zmiany zachodzące $\mathrm{w}$ następnych stuleciach przekształciły obszary diecezji. Lubomir Bieńkowski zwraca uwagę na wydłużony kształt biskupstwa włodzimiersko-brzeskiego (unickiego), obejmującego w XVIII w. zachodnie obszary Wołynia, Polesia i południowej części Podlasia. Diecezja ta została podzielona na dwie części przez włość lubomelską i rateńską, należące do biskupstwa chełmskiego. Obszar dwóch diecezji pokrywał się z XIII-wiecznymi granicami księstw dzielnicowych: chełmskiego i włodzimierskiego. Księstwo włodzimierskie, obejmujące również Luboml i Ratno, w I poł. XV wieku zostało wcielone do ziemi chełmskiej, a tym samym do Korony. Na podstawie tych zmian można przypuszczać, że granice biskupstw pokrywały się z granicami państwowymi i administracyjnymi wewnątrz państwa (Bieńkowski, 1969, 
s. 795-796) ${ }^{2}$. Wobec powyższego, południowe obszary Podlasia, zanim weszły w skład eparchii włodzimierskiej, należały do końca XIII wieku do diecezji chełmskiej (Batiuszkow, 1887, s. 38) ${ }^{3}$. Zmiany granic księstw i ziem w XIV wieku podporządkowały obszar po obu stronach Bugu biskupowi włodzimierskiemu. Południowa granica biskupstwa włodzimierskiego sięgała Włodawy. Granica ta uległa zasadniczym zmianom po przyjęciu przez władyków włodzimierskich unii. Problemem spornym pozostawał północny zasięg diecezji. Jurysdykcyjne podporządkowanie poszczególnych cerkwi podlaskich wskazuje, że obszar biskupstwa pokrywał się, z niewielkimi różnicami, z zasięgiem katolickiej diecezji łuckiej. Również i w tym wypadku Wołyń od Podlasia oddzielony był włością ratneńską podległą Koronie i ordynariuszowi chełmskiemu. Do łacińskiej diecezji łuckiej należały ziemie: drohicka, bielska, mielnicka i brzeska. Granica północna tego biskupstwa przebiegała wzdłuż rzeki Narwi $\mathrm{z}$ niewielkimi odchyleniami ku województwu trockiemu. Granica zachodnia diecezji sięgała rzeki Liwca (Trajdos, 1983, s. 104-105) ${ }^{4}$. Katolicka diecezja łucka graniczyła na Podlasiu z biskupstwem wileńskim. Granice tego biskupstwa wyznaczały dekanaty grodzieński, augustowski i knyszyński. Pierwszy opis diecezji wileńskiej z 1522 roku wymienia parafie w Goniądzu i Kalinówce. Dokumenty fundacyjne wskazują na istnienie w XVI wieku kościołów w Augustowie, Knyszynie, Turośni, Dobrzyniewie, Krynkach i Brzostowicy Wielkiej (Kurczewski, 1912, s. 177) ${ }^{5}$. Wyszczególnione w wykazach parafie

\footnotetext{
Biskupstwo chełmskie powstało w XIII wieku z włodzimiersko-wołyńskiego. Objęło ono obszar ziemi chełmsko-bełzkiej. W skład jego wchodziła Chełmszczyzna i niektóre terytoria ziemi wołyńskiej, halickiej oraz włości ratneńsko-lubomelskiej. Rozmieszczenie diecezji na ziemiach W. Ks. Lit. było nierównomierne. Na południowo-zachodnim obszarze metropolii skupiało się w XVI wieku pięć biskupstw, obejmujących czwartą część jej terytorium (chełmskie, przemyskie, halickie, włodzimierskie i łuckie). Dwukrotnie większe od wyżej wymienionych władyctw były eparchie: smoleńska i połocka, a wszystkie przytłaczała swymi rozmiarami diecezja metropolitarna. Dodatkową trudność w ustaleniu rzeczywistych siedzib biskupich była częsta zmiana tytulatury poszczególnych władyków. Np. biskup turowski tytułował się jako piński, a halicki jako halicki, lwowski i kamieniecki. Ordynariusz przemyski określany był jako samborski (w XVI wieku dodatkowo sanocki), chełmski jako chełmsko-bełzki, łucki jako łucko-ostrogski, smoleński jako smoleńsko-siewierski, witebski jako witebsko-mścisławski (a w XVIII wieku dodatkowo mohylowsko-orszański). Wieloczłonowość tytułów władyków prawosławnych wynikała z lokalizacji katedr diecezjalnych. Nazwy miejscowości wyszczególnionych w tytułach biskupów odpowiadały zazwyczaj ośrodkom jednostek administracyjnych i ziem. Tytulaturę poprzednią stosowano przy przeniesieniu siedziby biskupstwa do nowej miejscowości. Np. z Turowa do Pińska (turowsko-piński) czy z Halicza do Lwowa (halicko-lwowski).

Autor zwraca uwagę, że granice władyctwa chełmskiego w 1276 roku sięgały po rzekę Bug.

4 Przyłączenie do katedry łuckiej parafii katolickich z ziemi drohickiej i mielnickiej znacznie wzmocniło biskupstwo wystawione na silną rywalizację a prawosławną diecezją włodzimierską.

Dokładny spis parafii w dekanatach grodzieńskim, augustowskim i knyszyńskim posiadamy dopiero z 1669 roku. Sporządzony przez Aleksandra Sapiehę, wymienia on parafie:

a) dekanat grodzieński: Grodno, Przewałka, Oza, Jeziora, Kwasówka, Ejsmonty, Brzostowica Mała, Krynki, Szudziałowo, Odelsk, Indura,
}

wskazują, że granica między katolicką diecezją wileńską a łucką w XVI wieku przebiegała wzdłuż rzeki Narew, zostawiając przy ostatnim biskupstwie Tykocin, Suraż i Narew. Był to zapewne efekt zmian osadniczych, podziałów administracyjnych i własnościowych, o czym świadczą enklawy podległe diecezji łuckiej na terenie biskupstwa wileńskiego i diecezji wileńskiej w biskupstwie łuckim (Wiśniewski, 1980, s. 116).

Wobec powyższego można przypuszczać, że granica podlaska między dwoma diecezjami prawosławnymi (włodzimierską i metropolitarną) pokrywała się z granicą między biskupstwami katolickimi (łuckim i wileńskim). Bliższa analiza przynależności parafialnej poszczególnych cerkwi prawosławnych w XVI wieku nakazuje zweryfikowanie takich założeń. Aleksander Jabłonowski w monografii o Podlasiu wyraził wątpliwość w sprawie przynależności Tykocina do diecezji włodzimierskiej. ,Nie wiadomo czy Zanarewie powiatu tykocińakiego należało do eparchii włodzimierskiej, prędzej chyba ta krawędź Podlasia podlegała zwierzchnictwu bezpośrednio metropolii w Nowogródku albo archiepiskopii połockiej" (Jabłonowski, 1909, s. 227). Według Jerzego Wiśniewskiego taki podział cerkiewny był wynikiem przebiegu i charakteru etnicznego nowego osadnictwa. Osadnictwo wołyńskie ostatecznie swym zasięgiem objęło południowe obszary ziemi podlaskiej po górny bieg rzek: Nurca, Narwi, Narewki, Kamieniec i Puszczę Bielską. Ziemie nad Narwią i Bugiem weszły w skład prawosławngo władyctwa włodzimierskiego. Terytorium jego było oddzielone od obszarów znad Niemna i innych ośrodków litewsko-białoruskich pasem puszcz, ciągnących się od bagien poleskich po dawne puszcze jaćwieskie. W wyniku zagospodarowania Puszczy Bielskiej w XVI wieku wielu poddanych grodu bielskiego i surażskiego przekroczyło granice rzeki Narwi, dając początek miejscowościom (np. Żuki, Iwanki, Solniki) (Wiśniewski, 1980, s. 15-18), które podlegały jurysdykcji biskupów włodzimiersko-brzeskich. Pomimo dobrze rozwiniętych badań historyczno-osadniczych Białostocczyzny, nie podjęto dotąd próby zrekonstruowania podlaskiej granicy między dwoma biskupstwami prawosławnymi.

Rekonstrukcję taką należy podjąć z uwagi na ukazanie mechanizmów kształtujących strukturę organizacyjną Kościoła prawosławnego. Z uwagi na charakter pracy badania nad przebiegiem podlaskich granic władyctw: metropolitarnego i włodzimierskiego ograniczam do terytorium obecnego obszaru Polski. Pierwotnie (tj. do XVI w.) granica diecezji biegła od obecnej granicy państwowej wzdłuż rzeki Narew do miejsca, gdzie rzeka przecinała dawną gra-

Kuźnica, Kondzyń, Sokółka, Sokolany, Dąbrowa, Zalesie, Nowy Dwór, Krasnybór, Lipsk, Różanystok;

b) dekanat augustowski: Augustów, Grabowo, Baryłów, Rajgród, Goniądz, Trzciane, Tykocin, Dobrzyniewo, Jesionówka, Brzozowa Major, Dolistowo;

c) dekanat knyszyński: Kalinówka, Brzozowa Minior, Knyszyn, Krypno, Choroszcz, Niewodnica, Turośnia, Juchnowiec, Zabłudów, Białystok, Wasilków, Korycin, Chodorówka

Nie wszystkie wymienione parafie powstały w XVI wieku. Miejscowości te wyznaczają jednakże przybliżone do XVI - wiecznych granice południowe diecezji wileńskiej na ziemi podlaskiej. 
nicę województw nowogródzkiego i podlaskiego, a dalej na północ wzdłuż wschodniej granicy województwa podlaskiego do styku obszaru trzech województw: podlaskiego, trockiego i nowogródzkiego. Taki przebieg linii, rozgraniczającej obie diecezje, był spowodowany podziałem administracyjnym i zasięgiem oddziaływania osadnictwa białoruskiego i wołyńskiego. Puszcza Wołpińska znajdowała się pod dominacją ludności nadroskiej i nadświsłockiej. Puszcza Grodzieńska była zagospodarowana przez osadników nadniemeńskich. Z południa aż do rzeki Narwi osiedlała się ludność pochodzenia wołyńskiego. Warto zaznaczyć, że ówczesne granice puszczańskie nie tylko ustalały przynależność administracyjną i gospodarczą puszcz, lecz wytyczały na tym terenia zasięg osadnictwa i zależność diecezjalną. Granice diecezjalne ukształtowały się znacznie wcześniej aniżeli ostateczny kształt granic województw. Południowe krańce podlaskiej części władyctwa metropolitarnego wyznaczone były na tym odcinku zasięgiem Puszczy Wołpińskiej i starostwa jałowskiego. Południowe granice starostwa przebiegały wzdłuż rzeki Narwi - ze wsiami Cisówka, Krugły Lasek, Rybaki, Rudnia i Szymki (Ciwoniuk, 1983, s. 5-6). W II poł. XVI wieku przebieg granicy między biskupstwami uległ na tym odcinku zasadniczej zmianie. Obszar między Narwią a Narewką (Puszcza Narewska) w XVI wieku otrzymali kniaziowie Massalscy. Zagospodarowaniem terenów puszczańskich zajęli się sprowadzeni przez nich osadnicy z dóbr Brzostowica i Olekszyce. Osadnictwo podgrodzieńskie przekroczyło więc górną Narew i dotarło do rzeki Narewki, nad którą nastąpiło zetknięcie się z osadnictwem wołyńskim. Dobra rodowe Massalskich jurysdykcyjnie podlegały władyctwu metropolitarnemu i ich nowy zasięg stał się podstawą do ustalenia południowej granicy województwa nowogródzkiego i diecezji kijowskiej. Granica diecezjalna przebiegała więc zgodnie z linią rozgraniczającą obszary województwa podlaskiego i nowogródzkiego aż do styku z województwem trockim. Najbardziej wysuniętą na północ parafią biskupstwa włodzimierskiego było Lewkowo Stare, położone za rzeką Narwią, lecz pozostające na terytorium województwa brzeskiego.

Dalszy przebieg granicy między diecezjami pokrywał się z południową granicą województwa trockiego do końca gruntów starostwa rybołowskiego i puchłowskiego, należących już do województwa podlaskiego. Powstanie na północ od rzeki Narew parafii prawosławnych podległych biskupstwu włodzimierskiemu związane było z kolonizacją Puszczy Bielskiej. Nowe osadnictwo objęło na pocz. XVI wieku szerokim pasem puszcze od granicy włości kamienieckiej po rzekę Narew i poza nią do styku włości bielskiej z dobrami zabłudowskimi i starostwem jałowskim. Najbardziej wysuniętymi parafiami należącymi do eparchii włodzimierskiej na tym terenie były Antonowicze (Ryboły) i Puchły, powstałe w centrum wójtostw włości bielskiej.

O ile omówiony odcinek granicy biskupstw kształtował się pod wpływem podziałów administracyjnych i osadniczych, to następny jej fragment określony został przez strukturę własnościową. Dobra Biały Stok i Dojlidy nada- ne przed 1450 r. przez Kazimierza Jagiellończyka Raczce Tabutowiczowi zostały zagospodarowane przez jego następców - Jundziłłów, Bakałarzewiczów i Raczkowiczów. Przed 1483 rokiem król nadał marszałkowi kijowskiemu Iwanowi Chodkiewiczowi Puszczę Błudowską, ciągnącą się od wsi należących do włości bielskiej i surażskiej (wsie Małynka i Czarna) po źródła Białegostoku. Oprócz Puszczy Błudowskiej syn Chodki Juriewicza otrzymał Gródek z Puszczą Supraską i dobra Choroszcz. Iwan Chodkiewicz nie skolonizował otrzymanych nadań. Zmarł w niewoli tureckiej około 1484 r. Właściwym kolonizatorem odzyskanych nadań był Aleksander Chodkiewicz, który powiększył swe dobra o Dojlidy, kupione w 1528 r. od Macieja i Mikołaja Jundziłłów. W 1498 roku osadzając zakonników w Gródku, zapoczątkował fundację słynnego monasteru supraskiego, który otrzymał w uposażeniu wsie Topilec, Baciuty, Zawady, Zaczerlany, Kościuki i Gajewniki oraz miasto Choroszcz, zamienione przez fundatora w 1533 roku na dobra Fasty i Klewinowo. Podległość monasteru supraskiego i dóbr chodkiewiczowskich jurysdykcji metropolitów kijowskich spowodowała, że północna granica biskupstwa włodzimierskiego przebiegała wzdłuż gruntów wsi należących do klasztoru i Chodkiewiczów. Naturalną jej postacią była granica między Puszczą Surażską a Bielską, zaczynająca się od rzeki Narew między Kożanami (strona suraska) a Wojszkami (strona bielska) i biegnąca dalej na północ do granicy województwa trockiego, zostawiając po stronie diecezji włodzimierskiej wsie włości bielskiej: Wojszki, Ryboły, Pawły i Puchły (Wiśniewski, 1985, s. 20; Mironowicz, 1991, s. 68-69). Na terenie eparchii metropolitarnej znalazły się niektóre wsie starostwa suraskiego, które weszły jako uposażenie monasteru supraskiego. Niewątpliwie jednak obie cerkwie suraskie wraz z kaplicą w Zawykach należały do biskupstwa włodzimierskiego. Dalsza granica tego biskupstwa była zgodna z zasięgiem starostwa suraskiego, a następnie biegła wzdłuż rzeki Narew do granicy starostwa tykocińskiego. Wsie tego starostwa wchodziły w skład diecezji metropolitarnej. Najdalej wysuniętymi na południe miejscowościami biskupstwa metropolitarnego były Pajewo, Radule, Lipniki, Stelmachowo, Babino i Złotoryja.

W Kościele prawosławnym diecezje dzieliły się na protopopie - namiestnictwa, będące odpowiednikiem łacińskich dekanatów. Namiestnicy biskupów (protopopi) byli wybierani spośród kryłoszan ${ }^{6}$ i zatwierdzani przez ordynariuszy. Struktura organizacji cerkiewnej często pokrywała się z istniejącą strukturą administracji państwowej. Siedziby protopopii powstawały więc w ośrodkach państwowych, jednostkach administracyjno-sądowych, stolicach ziem i powiatów. Do tej roli predestynowały ośrodki

\footnotetext{
Kryłoszanie to protopopi i protoprezbiterzy, którzy stanowili ciało pomocnicze dla biskupa. Kryłosy (klirosy - od greckiego klerom - duchowieństwo) stanowiły organ administracyjno-sądowniczy diecezji skupionych w centrach eparchialnych. Zakres obowiązków i uprawnień nie był ściśle określony. Pozycja ich i kompetencje były określane przez biskupów i prawo zwyczajowe.
} 
administracyjne ze względu na skupienie w nich większej liczby cerkwi i duchowieństwa. Do zadań protopopów należało nadzorowanie $\mathrm{w}$ imieniu biskupa życia cerkiewnego w podległej mu protopopii. Namiestnicy nadzór swój sprawowali poprzez wizytacje parafii, czuwanie nad stanem moralnym duchowieństwa, troskę o majątek cerkiewny, kontrolę pracy duchowieństwa. Protopopi pobierali opłaty od duchowieństwa na rzecz utrzymania biskupa diecezjalnego, za co otrzymywali dodatkowe wynagrodzenie. Dochody protopopów były zdecydowanie większe niż proboszczów parafialnych. Dostrzegali to autorzy uniwersału poborowego z 1580 roku, na podstawie którego proboszcz parafialny płacił dwa złote, a protopop cztery (Voluminam Legum, 1859, s. 199).

W podlaskiej części diecezji włodzimierskiej zarząd nad Cerkwią należał do trzech protopopów: bielskiego, drohickiego i brzeskiego (Jabłonowski, 1902, s. 227). Na pocz. XVI wieku w podlaskiej części diecezji metropolitarnej decydującą rolę odgrywał protopop grodzieński. Namiestnictwo grodzieńskie wymienione zostało obok wileńskiego, nowogródzkiego, słuckiego, smoleńskiego, wołkowyskiego i markowskiego w aktach synodu wileńskiego z 1509 roku (Opisanije Kijewsko-Sofijskogo sobora i kijewskoj jeparchii, 1825, s. 42; Bieńkowski, 1969, s. $809)$. Wobec niewielkiej wówczas liczby parafii protopopia grodzieńska obsługiwała wszystkie parafie północnej części województwa podlaskiego i zachodniej części województwa trockiego.

Wzrost liczby parafii zmusił władze Kościoła prawosławnego do tworzenia nowych protopopii. Wielkość ich ulegała zmianie przy nowych podziałach administracyjnych. Przy wyodrębnianiu się nowej protopopii podlaskiej w biskupstwie metropolitarnym w II poł. XVI wieku ważną rolę odegrały stosunki własnościowe. Grzegorz Chodkiewicz, kończący w latach sześćdziesiątych proces zagospodarowania dóbr rodowych, doprowadził do utworzenia nowej protopopii obejmującej swym zasięgiem cerkwie leżące na terenie jego włości i znajdujące się pod jego patronatem. Siedzibą protopopii została rezydencja rodowa w Zabłudowie. Wkrótce jednak nowo utworzone namiestnictwo rozszerzyło swoją zwierzchność poza dobra Chodkiewiczów i ich spadkobierców. W 1583 roku protopop zabłudowski Nestor Kuźmicz wydał posłanie do całego duchowieństwa podlaskiego jako jego zwierzchnik - ,protopopa podlaski” (Jabłonowski, 1909, s. 227). Brak wykazu cerkwi poszczególnych protopopii nie pozwala na dokładne określenie granic między namiestnictwem zabłudowakim a grodzieńskim. Można jedynie przypuszczać, że granica ta przebiegała w końcu XVI wieku wzdłuż pasa puszcz (Puszcza Kryńska) Odelska, Malawicka, Kuźnicka). Terytorium protopopii bielskiej i drohickiej pokrywało się z granicami ziem. Ziemia mielnicka znajdowała się w jurysdykcji namiestników brzeskich.

Protopopie dzieliły się na parafie. Z zachowanych wykazów cerkwi diecezji chełmskiej wynika duże zróżnicowanie liczb parafii przypadających na jedno namiestnictwo
(Bieńkowski, 1969, s. 814) ${ }^{7}$. Protopopie podlaskie liczyły od kilkunastu do kilkudziesięciu parafii. Najliczniejszymi z nich były protopopie: brzeska, bielska i drohicka. Kościół prawosławny na Podlasiu posiadał rozbudowaną sieć parafialną. Pobieżne przyjrzenie się rozmieszczeniu parafii wskazuje na duże zróżnicowanie ich liczby w poszczególnych diecezjach, ziemiach, wsiach i miastach. Największe zagęszczenie parafii znajduje się między rzeką Krzną a Narwią. Im dalej na północ i zachód tym terytorialna wielkość parafii i liczebność wiernych stawała się większą, a ich liczba malała. Decydującym czynnikiem kształtującym liczbę parafii był stan osadnictwa ruskiego i stopień zagospodarowania poszczególnych ziem.

Struktura parafii cerkiewnych ukształtowana na pocz. XVI wieku stała się podstawą do podziału administracyjnego. Wykaz wojskowy szlachty podlaskiej z 1528 roku został ułożony parafiami. Ich liczba w ciągu stulecia wzrastała w wyniku rozwoju gospodarczego ziemi podlaskieji zmian w strukturze własnościowej. Dlatego też rejestr poborowy z 1580 roku wykazuje więcej parafii kościelnych aniżeli administracyjnych. Szybki rozwój sieci parafii prawosławnych był spowodowany kilkoma czynnikami: rozwojem osadnictwa ruskiego, związanego z zagospodarowaniem ziemi podlaskiej; fundacją nowych, cerkwi w lokowanych miasteczkach i wsiach, na nieskolonizowanych terenach; budową drugich lub trzecich obiektów cerkiewnych obok już istniejących w miastach i wsiach; usamodzielnieniem się cerkiewnych placówek filialnych; podziałem majątkowym i związanym $\mathrm{z}$ tym dążeniem szlachty podlaskiej do zespolenia poddanych dodatkową - oprócz zależności osobistej i gospodarczej - więzią parafialną (Mironowicz, 1991, s. 68-69).

Rozwój gospodarczy Wielkiego Księstwa litewskiego w II poł. XV wieku nie ominął znajdującej się w jego granicach ziemi podlaskiej, Zagospodarowanie jej przez książąt litewsko-ruskich pociągnęło rozwój osadnictwa ruskiego nad Krzną, Bugiem, Narwią i Biebrzą. Osadnictwo ruskie zdominowało obszar południowego Podlasia, a na północ od rzeki Bug zwartym obszarem sięgało okolic Brańska i Suraża. Szczególnie ludna była kolonizacja ruska koło Brańska, sięgająca aż po rzekę Mień. Zbudowano na tym terenie najdalej wysuniętą na zachód cerkiew wiejską w Hodyszewie. Najdalszymi na zachód wyspami ruskimi z cerkwiami były miasta prywatne Ciechanowiec i Wysokie (Mazowieckie). To ostatnie, ze wsiami ruskimi Osipy, Bożegi i Bryki, podlegało namiestnikowi z Drohiczyna (Wiśniewski, 1977, s. 17, 1980, s. 16). Liczne były fundacje cerkwi przez książąt litewsko-ruskich w starych miastach jak Suraż, Bielsk, Drohiczyn i Mielnik.

Elementem wzmacniającym rządy litewskie na zachodnich obszarach Wielkiego Księstwa Litewskiego było nadawanie przedstawicielom możnowładztwa litewsko-ruskiego puszcz i starostw. Zagospodarowanie ich zwiększyło napływ osadników litewskich i ruskich.

Spośród siedmiu protopopii z zachowanego wykazu cerkwi najwięcej parafii liczyła protopopia chełmska - 59, najmniej lubelska - 14. Pozostałe, tj. hrubieszowska, lubomelska, potylicka, rateńska i szczebrzeszyńska posiadały od 19 do 34 cerkwi. 
W 1433 roku Zygmunt Kiejstutowicz nadał Tykocin z przyległą włością swemu marszałkowi Janowi Gasztołdowi. Gasztołdowie, poprzez wykupywanie wsi szlacheckich, powiększyli znacznie swe dobra i dla osiedlającej się ludności ruskiej założyli cerkiew w Tykocinie (Kuźmińska, 1927, s. 135-171; Wiśniewski, 1977, s. 24). Kolonizując na pocz. XVI wieku Puszczę Knyszyńską Mikołaj Radziwiłł osiedlał w niej Rusinów, Litwinów i Mazowszan. Polityka osadnictwa magnatów litewskich doprowadziła do etnicznego przemieszania między Narwią, Biebrzą Brzozówką i Supraślą. Dla Rusinów założone zostały cerkwie w Knyszynie i Boguszewie (Wiśniewski, 1977, s. 25; Aleksandrowicz, 1968, s. 295) ${ }^{8}$. Inna gałąź Radziwiłłów ufundowała cerkiew w Sworach i swej rodzinnej rezydencji w Białej (Batiuskow, 1887, s. 729). Iwan Sapieha, sekretarz królewski, po otrzymaniu od króla w 1509 roku dobrze już zasiedlonej włości boćkowskiej, ufundował w Boćkach obok już istniejącej drugą cerkiew parafialną ( Wiśniewski, 1977, s. 23). Podobnie Paweł Iwanowicz Sapieha marszałek Wielkiego Księstwa Litewskiego, w swej rezydencji kodeńskiej wybudował w 1500 roku cerkiew pw. św. Michała. Aleksander Chodkiewicz był fundatorem oprócz monasteru supraskiego cerkwi w Gródku i Zabłudowie. We wsiach stanowiących uposażenie tegoż klasztoru powstają trzy samodzielne jednostki parafialne. Za pomoc okazaną królowi w wojnie moskiewskiej władyka smoleński Józef Sołtan otrzymał nadanie na Podlasiu (Topilec, Baciuty, Piszczewo). Metropolita Sołtan postawił tu dwór władyczy, a następnie nadanie w całości odstąpił w 1506 roku monasterowi supraskiemu (Wiśniewski, 1985, s. 22). Ufundowane w Topilcu i Baciutach kaplice przekształciły się w ciągu XVI wieku w samodzielne parafie, choć jurysdykcyjnie podlegały archimandrytom supraskim. Przy podziale dóbr po Raczce Tabutowiczu między synów, doszło do konfliktu między nimi, w którego toku Michno Raczkowicz zabił Jana Raczkowicza. Na części Jana Raczkowicza, która według J. Wiśniewskiego odebrana została przez Kazimierza Jagiellończyka, powstały dobra Chwasty (Fasty) obejmujące wsie Bacieczki, Łyski, Porosty i Krupniki. Dobra te w 1483 roku znalazły się w rękach Chodkiewiczów. Aleksander Chodkiewicz wzamian za nie odebrał w 1533 roku za zgodą królewską od monasteru supraskiego Choroszcz z włością (Wiśniewski, 1985, s. 16-17). Zapewne jeszcze kiedy Fasty stanowiły własność Chodkiewiczów, powstała w nich cerkiew. Parafia prawosławna w Choroszczy powstała razem z nadaniem praw miejskich w 1507 roku (Aleksandrowicz, 1970, s. 82).

Typowymi funkcjami cerkwi dla Rusinów na terenach nowozagospodarowanych były erekcje parafii w Wołkuszu i Kuźnicy (Białostockiej) - Bohufałów, Kuścinie-Koszyrskich, Sasinach i Rohaczach-Kaleczynckich, Rogowie-Ostikowiczów, Gnojnie-Niemirów czy Dołhaj-Czetwertyńskich (Żychliński, 1896, s. 13; Gloger, 1903, s. 174). Znaczna część parafii prawosławnych po-

\footnotetext{
8 Parafia w Boguszewie założona została przez wojewodzinę płocką Petronelę Radziwiłłównę Dowojnową między 1545 a 1564 r.
}

wstawała wraz z lokacją miast i wsi. Podczas zagospodarowania górnej Narwi założono w 1545 roku miasto Jałówkę i ufundowano w nim cerkiew prawosławną (Wiśniewski, 1977, s. 47). Wśród miejscowości założonych przez królową Bonę znalazło się Jaczno z cerkwią dla obsługi mieszkającej tam ludności (1540) (Wiśniewski, 1977, s. 38;). W trakcie kolonizacji Puszczy Nowodworskiej założono przed 1539 rokiem osadę (miasteczko) Nowy Dwór wraz z cerkwią (Wiśniewski, 1977, s. 30). Szczególnie fundacje królewskie charakteryzowały się jednoczesną fundacją miast i cerkwi, gdy na terenie lokowanym zamieszkała ludność prawosławna. Erekcja parafii prawosławnej w Lipsku nastąpiła w dwa lata po nadaniu praw miejskich (1580) (Wiśniewski, 1697, s. 618-619). Cerkiew prawosławna w Augustowie powstała przed uzyskaniem praw magdeburskich (1557 r.) i wybudowano ją w trakcie pierwszej lokacji miasta królowej Bony. Bogdan Wołowicz obok nowozałożonego dworu Dowspuda wzniósł cerkiew dla zamieszkałej tam ludności ruskiej (Wiśniewski, 1962, s. 425-436; 1965, s. 15). Inwentarz z 1569 roku wymienia ponadto ,sioło Lipskie nowo założone na uroczysku Szkieblewo" z cerkwią parafialną (Wiśniewski, 1965, s. 89). Głównym powodem fundacji cerkwi w nowolokowanych wsiach było zapewnienie obsługi potrzeb religijnych osiedlającej się tam ludności. Ten sam cel przyświecał powstaniu parafii prawosławnej w Krasnymborze nowozałożonym centrum dóbr Teodora Chreptowicza (1513 r.) (Wiśniewski, 1965, s. 126) czy w nowolokowanenj wsi Szóstka, w której Stefan Zbaraski ufundował cerkiew pw. Narodzenia NMP (1551 r.).

Zagęszczenie sieci parafii prawosławnych następowało poprzez fundację nowych cerkwi w istniejących już miejscowościach lub wybudowanie drugiego i trzeciego obiektu cerkiewnego w miastach i wsiach posiadających parafię. Potrzeba erygowania nowych parafii nie zawsze były wynikiem rzeczywistych potrzeb w obsłudze religijnej ludności. Nader często względy majątkowe i prestiżowe odgrywały większą rolę aniżeli dewocjonalne. Możnowładcy w fundacji cerkwi widzieli sposób umocnienia swojej pozycji społecznej. Wreszcie prawo ktitorstwa i patronatu dawało im nieograniczone możliwości wpływania na duchowieństwo i wiernych. Znaczna część nowych parafii powstała w miastach prywatnych po objęciu ich przez nowych właścicieli. Mikołaj Sapieha po objęciu Kodnia w 1550 r. ufundował w nim cerkiew św. Mikołaja i wystarał się o erekcję parafii w Lebiedziowie (Pełczyński, 1911, s. 149-150; Alexadrowicz, 1969, s. 123). Powstanie dwóch parafii na terenie Międzyrzecza nastąpiło po wybudowaniu w 1582 roku przez Stefana Zbaraskiego cerkwi św. Ap. Piotra i Pawła obok już istniejącej parafii św. Mikołaja erygowanej w 1564 roku dzięki staraniom Jana Mikołaja i Zofii Żurawy Daniłowiczów. Przykładami budowy nowych cerkwi w istniejących już dawniej miejscowościach mogą być fundacje cerkwi w Sawiczach Ruskich, Piszczacu (królewska), Nosowie czy Gnojnie (Pełczyński, 1911, s. 149-150; Alexadrowicz, 1969, s. 121-123; Wawrzyńczyk, 1951, 
s. 39-43; Teodorowicz, 1905, s. 28; Wędzki, 1974, s. 40$41)^{9}$. Nie zawsze jednak wybudowanie nowej cerkwi oznaczało powołanie do życia nowej parafii. Potwierdzeniem tego mogą być fundacje Wasyła Połubińskiego. Cerkiew wybudowana w Horodyszczu w 1550 roku otrzymała bogate uposażenie pozwalające na utrzymanie trzech duchownych i diakona. Wzniesiona potem przez Połubińskiego świątynia w Połubiczach pozostała cerkwią filialną. Podobne relacje wystapiły w dobrach Joanny Połubińakiej między nowowzniesionymi cerkwiami we wsi Jabłonie i Paszenki. Mimo istnienia w dobrach orlańskich dwóch cerkwi i bogatego uposażenia proboszcza, właściciele Orli nie wyrazili zgody na utworzenie drugiej parafii na terenie miasta. Świadczą o tym akta fundacyjne cerkwi orlańskiej z 1520 roku Bohusza Bohowitynowicza, podskarbiego litewskiego i akty nadań ziemskich z lat 1520 , 1524, 1543 i 1596, w których mowa jest o jednym proboszczu i dwóch cerkwiach. Budowa drugiej cerkwi św. Symeona Słupnika nastapiła około 1516 roku, po objęciu dóbr orlańskich przez Bohowitynowiczów. Zapewne poprzedni właściciel Orli - Jesko Iwanowicz był fundatorem cerkwi św. Jana Złotoustego (1500 r.). W tym wypadku objęcie całości dóbr orlańskich przez Bohowitynowiczów zapobiegło podziałowi parafii. Bogusz Bohowitynowicz był również ktitorem cerkwi w Sławatyczach (Wiśniewski, 1977, s. 23).

Znaczny wzrost liczby cerkwi parafialnych na Podlasiu należy thumaczyć pobudkami natury pozareligijnej. Wybudowanie i uposażenie drewnianej najczęściej cerkwi oraz zapewnienie, skromnych na ogół, środków egzystencji duchownym nie były przedsięwzięciem kosztownym. Założenie parafii przynosiło właścicielowi dóbr lub ich dzierżawcy znaczne dochody. Szlachcic, będąc zarazem nominalnie ktitorem cerkwi, ograniczał się do nadania proboszczowi i jego rodzinie gruntów, najczęściej niezagospodarowanych i słabej jakości. Dochody płynące z obsługi religijnej ludności pozostawały na terenie dóbr właściciela i przeznaczone były na utrzymanie cerkwi, przez co ktitor zwolniony był w praktyce od wszelkich powinności finansowych na rzecz parafii. Sytuacja taka zachodziła przeważnie wówczas, kiedy dziedzicem lub dzierżawcą dóbr był przedstawiciel innego wyznania. Inicjatorem powstania parafii był wówczas kandydat na parocha i wierni.

W ten sposób powstała parafia w Sereczynie, gdzie nowa cerkiew wybudowana została dzięki staraniom przyszłego proboszcza, Jaczka Wierzbowicza ,za pozwoleniem i przywilejem" starosty drohickiego Mikołaja Kiszki, który nakazał poddanym seroczyńskim, aby oddawali dziesięcinę do nowej cerkwi, a nie dotychczasowej w Łazowie. Starosta drohicki nakazywał przy tym, aby „wszastkie rzeczy y rozkazanie moje abyście koniecznie wypełniły y jemu tho co się na ten przywileju zawiera wiecznemi czasy oddawali pod wyną moją na każdego wkładając, gdzie by

Cerkiew św. Mikołaja Daniłowiczowie wybudowali na miejscu uprzednio istniejącej pod tym samym wezwaniem. Inicjatorem powstania pierwszej parafii na terenie miasta była Anna, córka Mikołaja Nassuta, która wraz z mężem Iwanem Zabrzezińskim na pocz. XVI wieku była właścicielem Międzyrzecza. się ważył inaczey czynić, a tego nie wypełniać dziesięciną grzywien polskich pieniędzy (...)" ( Lubawskij, 1892, s. 182$)^{10}$. Na prośbę mieszkańców wsi Rudna, Drewiczna i duchownego z Wołynia Marcina Lewonowicza miernicy dokonujący tam pomiarę ,obaczywszy iż bez cerkwi Bożej trudno mieszkały (...) dozwolili im w tom sele w Rudnie cerkow zbudowaty $\mathrm{i} k$ to $\mathrm{j}$ cerkwi obrati jego popom (...)". Decyzja miernika, namiestnika zabielskiego Mateusza Łewickiego została potwierdzona 15 lutego 1550 roku przywilejem królewskim przez Zygmunta Augusta. Wydanie zgody na utworzenie nowej parafii przez dzierżawcę czy starostę drohickiego nie było bezinteresowne, gdyż wiązało się z pobieraniem za nią opłaty.

Ordynariusze diecezji witali powstanie nowych ośrodków parafialnych z zadowoleniem. Wierni nie tylko uzyskiwali lepszą opiekę duszpasterską, ale zarazem przysparzali władykom dochodów z tytułu katedratyku. Prawo cerkiewne nie ograniczało rozwoju sieci parafialnej. O powstaniu niezależnej jednostki cerkiewnej decydowała wola właściciela dóbr, który mógł wprowadzić przymus parafialny dla swych poddanych. Parafianie nowej cerkwi często podlegali zakazowi uczestniczenia w nabożeństwach $\mathrm{w}$ innych parafiach, przyjmowania tam sakramentów i uiszczania wszelkich opłat. Taka rygorystyczna postawa właścicieli majątków wynikała nie tylko z chęci zapewnienia nowemu parochowi dochodów, ale i z dążności do zespolenia poddanych więzią parafialną. Względy te spowodowały, że niewielka wieś Gruzka, podzielona na pocz. XVI wieku między dobra Kaleczyckich i Sapiehów, posiadała dwie osobne parafie i dwóch prezbiterów ${ }^{11}$. Na Podlasiu udział biskupów ruskich w powstawaniu nowych parafii (poza monasterem supraskim, Topilcem i Baciutami) ograniczał się w praktyce do akceptacji istniejącego już stanu i udzielenia błagosłowieństwa prezentowanemu przez ktitora kandydatowi na proboszcza.

Wielkość podlaskich parafii prawosławnych wykazuje duże zróżnicowanie. W dobrach królewskich zamykały się one w granicach wójtostw lub dzierżaw. Na przykład cerkiew w Prochenkach obsługiwała ludność prawosławną wójtostwa szydłowskiego, a parafia kórnicka wójtostwa kornickiego . Lustracje i inwentarze z XVI wieku wska-

\footnotetext{
${ }^{10}$ Cerkiew w dobrach Sławatycze, otrzymanych od Aleksandra w 1499 roku, założył Ursuł Wołoszyn. W 1514 roku dobra te wraz z cerkwią przeszły w ręce Bohowitynowiczów.

11 Były też parafie powstałe z inicjatywy właściciela dóbr. Zofia z Tenczyna Daniłowiczowa, podskarbina koronna, w akcie fundacyjnym cerkwi NMP w Drechlowie z dnia 27 stycznia 1653 roku napisała ,isz ja widząc w szerokiej włości mej szczupłość domów Bożych, a szerokość parafiej, dla czego jako też i dla niedbalstwa swiaszczenników tamtejszych wiele ludzi takowych się znajduje, iż ledwo o Bogu wiedzą, wiary nie znają, a nawet siła się znajdzie i takich, że pacierza nie umieją, a to dla odległości miejsca, że wsi kilkanaście mając pod sobą jeden duchowny y to odległe od cerkwie za mil kilka wysługi duchownej duszom chrześcijańskim tak jako powinien oddać nie może, przeto umyśliłam dla rozmnażania, chwały Bożey, chcąc aby się rozszerzyła y ludzi w majętnościach mych w tak grubej prostocie nie żyli w Drechlowie, wsi dziedzicznej cerkiew założenia Niepokalanego Poczęcia Najświętszey Panny Maryey Bożey ufundować (..)".
} 
zują, że na obszarach zamieszkałych przez ludność ruską każde wójtostwo posiadało osobną parafię. Podobnie było z dzierżawcami. Dzierżawę narewską obsługiwała jedna parafia w Narwi . Istniejąca na jej terytorium parafia zakonna ograniczona była do niewielkiej części miasta. Sytuacja taka była we wszystkich miastach podlaskich. Parafie zakonne w niewielkim stopniu uczestniczyły w obsłudze religijnej ludności miasta. Rolę tę wypełniały parafie świeckie. Granic tych parafii na terenie miast królewskich, takich jak Bielsk, Drohiczyn, Suraż i Mielnik nie sposób dokładnie ustalić. Wydaje się, że zamykały się one w obrębie ulic bliskich cerkwi. Oprócz cześci miasta, każda parafia tego typu obejmowała wsie miejskie, w których najczęściej znajdowało się jej uposażenie ziemskie. Parafia pw. Zmartwychwstania Chrystusa w Bielsku posiadała w 1560 roku w swych granicach pół wsi Augustowo i Stryki. Odmiennie wyglądała sytuacja w dobrach prywatnych. W dobrach drobnoszlacheckich parafia była utworzona w centrum dóbr i obsługiwała ludność zamieszkałą na jej terenie. Często parafia taka ograniczała się do dwóch-trzech wsi. Np. Hanna Ostikowna ks. Lubecka ufundowała cerkiew w Rogowie (1546 r.) dla mieszkańców dwóch wsi Rogowa i Izbic. We wspomnianym wyżej kompleksie dóbr Bohowitynowiczów parafia orlańska obejmowała 13 miejscowości (Wiśniewski, 1977, s. 23). Dobra podlaskie Wołłowiczów obsługiwały dwie parafie: Dowspuda (włość szembelowską i wsie leśnictwa perstuńskiego) i Bala (Wiśniewski, 1967, s. 63) . Na terenie niewielkich i rozdrobnionych dóbr Kaleczyckich (włość Kaleczyce - Sasiny) powstało trzy parafie: Sasiny, Rohacze, Gruzka (Wawrzyńczyk, 1951, s. 95-96; Gloger, 1903 , s. 174 $)^{12}$. Liczba parafii w jednym kompleksie dóbr zależała od warunków terytorialnych. Dobra chodkiewiczowskie Gródek były wyspą w środku puszczy, stąd też utrzymanie stałego proboszcza $\mathrm{w}$ pierwotnej rezydencji rodowej stało się koniecznością.

Większe rozproszenie jednostek osadniczych w podlaskiej części diecezji metropolitarnej, przy słabym zaludnieniu, spowodowało dużą liczbę wsi przypadających na jedną parafię. Liczbę ich szacunkowo można ustalić na mniej więcej dziesięciu. Gęstsze zaludnienie i zwarta sieć parafialna w części diecezji włodzimierskiej zmniejszały liczbę wsi przypadających na jedną parafię średnio od 3 do 5. Należy przy tym pamiętać, że wiele parafii posiadało po dwie wsie. Podlaskie części obu biskupstw nie odbiegają zasadniczo pod względem liczby parafii i ich obszaru od pozostałych obszarów władyctw: włodzimierskiego i metropolitarnego. Ustalone występujące prawidłowości i średnie dane statystyczne można odnieść do całych eparchii.

Liczba parafii prawosławnych przed 1596 rokiem na terytorium zamykającym się we współczesnych granicach państwowych Polski, a obejmującym obszar województwa

\footnotetext{
12 Zygmunt I nadał w 1524 roku Sasinowi, wojewodzie brzeskiemu włość Kaleczyce (od której Sasinowie przybrali nazwisko Kaleczyckich). Siemien Kaleczycki i jego syn Wasyl fundując cerkiew w Kaleczycach (Sasinach) i Rohaczach nadali ich proboszczom uposażenie ziemskie. Na terenie otrzymanych dóbr była wieś Gruzka z osobną cerkwią.
}

podlaskiego i ziemie sąsiednie integralnie $\mathrm{z}$ nim związane, była zapewne większa aniżeli udało się ustalić . Luki w podstawie źródłowej uniemożliwiają w wielu przypadkach potwierdzenie istnienia w końcu XVI wieku cerkwi lub zakwalifikowanie istniejącej cerkwi jako samodzielnej jednostki parafialnej. Cechami charakteryzującymi istnienie parafii było: istnienie obiektu sakralnego (cerkwi) - najczęściej z placówkami filialnymi (kaplice), uposażenie proboszcza i pozostałego duchowieństwa oraz posiadanie odpowiednich warunków do funkcjonowania parafii (wierni, przynależność diecezjalna). Bez uwzględnienia wszystkich powyższych czynników nie sposób zakwalifikować wymienioną w źródłach cerkiew jako parafialną czy filialną. Tak np. zapis inwentarza wsi Kuraszewo o posiadaniu „dwóch włók przez popa ruskiego" nie może być wystarczającym dowodem do potwierdzenia istnienia tam parafii. Lustracja bowiem z 1576 roku wskazuje, że wymienione włóki w Kuraszewie należały do proboszcza cerkwi w Narwi .

Aleksander Jabłonowski określił liczbę parafii prawosławnych jako równą liczbie parafii katolickich na ziemi podlaskiej w XVI wieku i wynoszaca 75 samodzielnych jednostek kościelnych (Jabłonowski, 1909, s. 115-116) ${ }^{13}$. $\mathrm{Na}$ podstawie szczegółowej analizy źródłowej liczbę tę możemy zweryfikować. Z XVI wieku mamy informacje o 146 parafiach prawosławnych, a i ta liczba nie może być uznana za ostateczną, gdyż rozwój struktury parafialnej trwał aż do końca stulecia . Parafie te, oprócz cerkwi, posiadały placówki filialne i kaplice. Z ogólnej liczby podlaskich parafii prawosławnych 91 znajdowało się w dobrach prywatnych. Stanowiło to $63,3 \%$ ogólnej liczby parafii. Pozostałe 55 parafii $(37,7 \%)$ zorganizowane były w królewszczyznach . Stan taki był wynikiem struktury własnościowej i charakteru osadnictwa, zwłaszcza w południowej części ziemi podlaskiej. Z ogólnej liczby parafii podlaskich $117(80,7 \%)$ wchodziło w skład diecezji włodzimierskiej. $\mathrm{Na}$ terenie podlaskiej części diecezji metropolitarnej było zaledwie 28 parafii (19,3\%) (Mironowicz, 1991, s. 78). Taki podział rozwoju parafialnego był wynikiem stanu rozwoju gospodarczego poszczególnych ziem i charakteru osadnictwa na tym terenie. Osadnictwo ruskie zdominowało południowe i wschodnie ziemie podlaskie. Obszary na północ od rzeki Narew były kolonizowane aż do końca XVIII wieku, gdy procesy osadnicze na południu Podlasia zakończone zostały w zasadzie w I poł. XVII stulecia.

W miastach podlaskich skupionych było 55 parafii, co stanowiło $37,7 \%$ ogólnej ich liczby. Na wsi odnotowano istnienie 91 parafii (62,3\%) (Mironowicz, 1991, s. 78). Najwięcej parafii posiadały miasta, będące siedzibą władz administracyjnych - stolice ziem. Bielsk (Podlaski)

\footnotetext{
13 Obliczenia Jabłonowskiego ograniczone są zapewne do ziemi drohickiej i bielskiej. Nie wiadomo, czy autor monografii o Podlasiu uwzględnił cerkwie znajdujące się na zachodnich, obszarach województwa brzeskiego i trockiego integralnie związane z podlaską strukturą cerkiewną. Wartym podkreślenia jest ustalenie przez Jabłonowskiego, że liczba parafii cerkiewnych była o 1/3 większa aniżeli administracyjnych. Parafie administracyjne na Podlasiu obejmowały niekiedy dwie lub więcej parafii kościelnych.
} 
i Drohiczyn liczyły po 5 parafii. Po dwie parafie posiadały miasta: Kleszczele, Mielnik, Milejczyce, Narew, Suraż i Międzyrzec (Podlaski). Z wyjątkiem Międzyrzeca pozostałe miasta znajdowały się $\mathrm{w}$ dobrach królewskich . Wraz $\mathrm{z}$ nadaniem prawa magdeburskiego patronat mieszczan nad cerkwiami sprzyjał powstawaniu nowych parafii na terenie miasta. Ponadto $\mathrm{w}$ większych ośrodkach miejskich częstsze były fundacje królewskie i książęce. Np. cerkiew Narodzenia NMP w Bielsku na pocz. XVI wieku ufundowała księżna Wassa Holszeńska, żona kniazia Michała Semenowicza (Wolff, 1895, s. 4) ${ }^{14}$. Miasta prywatne, poza Międzyrzecem, były jednoparafialne. Wśród 146 parafii prawosławnych osiem z nich funkcjonowało przy monasterach: Bielsk, Drohiczyn (Przemienienia Pańskiego i św. Trójcy), Dokudów (Lewkowo), Jabłeczna, Milejczyce, Narew i Supraśl.

Kościół prawosławny na Podlasiu posiadał w końcu XVI wieku co najmniej 165 udokumentowanych obiektów sakralnych. Każda parafia posiadała kaplice i cerkwie filialne. Np. parafia w Opolu posiadała na swym terenie dwie cerkwie. Parafia w Nosowie miała swoją filię we wsi Bukowice (Aleksadrowicz, 1969, s. 113). Wobec powyższego należałoby liczbę parafii prawosławnych pomnożyć przez dwa obiekty sakralne; wówczas liczba 290 cerkwi i kaplic bardziej odpowiadałaby stanowi faktycznemu. Takie założenie statystyczne nie ukazałoby różnic w rozmieszczeniu obiektów sakralnych w rozbiciu własnościowym, diecezjalnym, między wsią a miastem. Dlatego też analiza tego zjawiska ograniczona została do 165 udokumentowanych cerkwi. Średnio przypadało ich 1,13 obiektu na parafię. Ich rozmieszczenie nie było równomierne. W 55 parafiach miejskich było 68 cerkwi (średnio na jedną parafię 1,24), a w 91 parafiach wiejskich znalazło się

\footnotetext{
14 Wassa, wnuczka Iwana Olgimontowicza, księcia holszańskiego i kijowskiego, była siostrą czwartej żony Władysława Jagiełły Zofii. Księżna holszanska dwukrotnie wychodziła za mąż; najpierw za księcia Iwana Olgierdowicza, a po jego śmierci za Michała Semenowicza. Cerkiew w Bielsku musiała ona ufundować przed 1484 rokiem, gdyż w tym roku zmarła.
}

97 obiektów sakralnych (średnio 1,07). Wynika z tego, że bogatszymi w obiekty sakralne były parafie miejskie aniżeli wiejskie. Zjawisko takie występowało zwłaszcza w diecezji włodzimierskiej. W 44 parafiach miejskich tego biskupstwa było 56 cerkwi (śr. 1,29), zaś w 74 parafiach wiejskich było ich 80 (śr. 1,08). W 11 parafiach miejskich diecezji metropolitarnej znajdowało się po jednej cerkwi. Po jednej cerkwi miało 17 parafii wiejskich tego biskupstwa. W sumie 118 parafii władyctwa włodzimierskiego posiadało 137 świątyń prawosławnych (śr. 1,16), zaś w eparchii metropolitarnej na Podlasiu suma parafii (28) odpowiadała takiej samej liczby cerkwi na ich terenie (Mironowicz, 1991, s. 79).

Zasadniczo niewielkie różnice w przypadającej liczby cerkwi na parafię położoną we włościach prywatnych (śr. 1,14 cerkwi na parafię) i królewskich (śr. 1,11) nabierają innej wymowy w rozbiciu na miasta i wsie. Otóż w 32 parafiach miejskich położonych $\mathrm{w}$ dobrach królewskich znajdowało się 38 cerkwi (śr. 1,19), a w 23 parafiach miejskich położonych we włościach prywatnych było ich 30 (śr. 1,30) (Mironowicz, 1991, s. 79-80). Wynika z tego, że miasta prywatne, niemal z reguły jednoparafialne, posiadały większą liczbę obiektów sakralnych aniżeli królewskie. Szybki rozwój parafii w miastach królewskich, zwłaszcza posiadających prawa magdeburskie, nie szedł w parze z fundacją placówek filialnych i kaplic. Fundacje takie były konieczne w miastach prywatnych. Parafie miejskie obsługiwały nie tylko ludność miejską, ale całość dóbr właściciela. Np. do parafii św. Mikołaja w Międzyrzecu należały dwie kaplice rozmieszczone we wsiach Żabice i Łukowisko (.......; Pełczyński, 1911, s. 149-150). Do utrzymania placówek filialnych i kaplic w dobrach prywatnych zmuszała właścicieli dóbr rozległość terytorialna parafii odpowiadająca często wielkości całej włości. Z tego też powodu budowano więcej cerkwi i kaplic w parafiach wiejskich położonych w dobrach prywatnych (91 parafii posiadało 104 cerkwie, śr. 1,14), aniżeli we włościach królewskich (55 parafii miało 61 cerkwi, śr. 1,11) (Mironowicz, 1991, s. 80).

\section{Bibliografia}

Aleksandrowicz, P. (1969). Stosunki religijne w Międzyrzeczu i okolicy. Rocznik Międzyrzecki, I. Międzyrzec Podlaski.

Alexandrowicz, S. (1970). Geneza i rozwój sieci miasteczek Białorusi i Litwy do połowy XVII wieku. Acta Baltico-Slavica, VII. Białystok.

Alexandrowicz, S. (1968). Mapy majątkowe północnego Podlasia. Kwartalnik Historii Kultury Materialnej, 14, 2, 295.

Batûškov, P. N.Holmskaâ Rus'.Istoričeskie sud'by russkogo Zabuž'â. Sankt - Peterburg. [Батюшков, П. Н.Холмская Русь. Исторические судьбы русского Забужья. Санкт - Петербург.].

Bieńkowski, L. (1969). Organizacja Kościoła wschodniego w Polsce. W: J. Kłoczouski (red.), Kościół w Polsce (t . II). Kraków.
Chodynicki, K. (1934). Kościót Prawosławny a Rzeczpospolita Polska (1370 - 1632). Warszawa.

Ciwoniuk, N. (1983). Rozwój osadnictwa w starostwie jałowskim od końca XVI do końca XVIII wieku w świetle toponimii. Kwartalnik Historii Kultury Materialnej, XXXI, 1, 5-6. Warszawa.

Gloger, Z. (1903). Dolinami rzek, opisy podróży wzdtuż Niemna, Wisty, Bugu i Biebrzy. Warszawa.

Gruševs'kij, M.S. (1907). İstorîa Ukraïni-Rusi. L'vìv - Kï̈v. [Грушевський, М.С. (1907). Історія України-Руси. Львів - Київ.].

Jabłonowski, A. (1909). Podlasie. Warszawa

Jabłonowski, A. (1902). Polska XVI wieku (t. 7, 8). Źródła dziejowe 19, 374-375. 
Kurczewski, J. (1912). Biskupstwo wileńskie. Wilno.

Kuźmińska, M. (1927). Olbracht Marcinowicz Gasztołd. Ateneum Wileńskie, IV, 135-171. Wilno.

Lûbavskij, M. (1892). Oblastnoe delenie i mestnoeupravlenie Litovsko-russkogo gosudarstva vo vremeni izdaniâ pervogo Litivskogo statuta. Istoričeskie očerki. Moskva. [Любавский, М. (1892). Областное деление и местное управление Литовско-русского государства во времени издания первого Литивского статута. Исторические очерки. Москва].

Makarij (1879). Istoriâ Russkoj Cerkvi (t. IX). Sankt-Petersburg [Макарий (1879). История Русской Церкви (Т. IX). Санкт - Петербург.].

Mironowicz, A. (1991). Podlaskie ośrodki i organizacje prawostawne w XVI i XVII wieku. Białystok.

Opisanie Kievosofijskogo sobora i kievskoj ierarhii.(1825). Kiev. [Описание Киевософийского собора и киевской иерархии. 1825. Киев.].

Pełczyński, A. (1911). Opis historyczno-statystyczny parafii międyrzeckiej. Warszawa.

Pokrovskij, I. (1897). Russkie eparhii v XVI-XIX vv., ih otkrytie, sostav i predely (Т. 1). Kazan'. [Покровский, И. (1897). Русские епархии в ХVI-XIX вв., их открытие, состав и предель (Т. 1.) Казань.].

Sosna, G. (1978). Historyczny zarys Kościoła prawosławnego od zarania dziejów do chwili obecnej na terenie województwa białostockiego. Wiadomości Polskiego Autokefalicznego Kościoła prawosławnego, 3-4, 64.

Teodorowicz, N. J. (1905). Gorod Radin i Miedziriecze Siedleckoj Guberni. Siedlce.
Trajdos, T. M. (1983). Kościół katolicki na ziemiach ruskich Korony i Litwy za panowania Władystawa Jagietty (13861434). Wrocław.

Wawrzyńczyk, A. (1951). Rozwój wielkiej własności na Podlasiu w XV-XVI wieku. Wrocław.

Wędzki, A. (1974). Problem genezy Międzyrzecza Podlaskiego na tle procesów urbanistycznych na południowo-zachodnim pograniczu Podlasia. Rocznik Międzyrzecki, VI. Międzyrzec Podlaski.

Wiśniewski, J. (1967). Dzieje osadnictwa w powiecie augustowskim od XV do XVII w. W: J. Antoniewicz (red.), Studia i materiały do dziejów Pojezierza Augustowskiego. Białystok.

Wiśniewski, J. (1965). Dzieje osadnictwa w powiecie suwalskim od XV do poł. XVII wieku. Studia i materiały do dziejów Suwalszczyzny. Białystok.

Wiśniewski, J. (1962). Nieznany oryginał dokumentu lokacji Augustowa z 1557 r. Rocznik Białostocki, 3, 425-436. Białystok.

Wiśniewski, J. (1977). Osadnictwo Wschodniej Białostocczyzny. Acta Baltico-Slavica, XI. Wrocław.

Wiśniewski, J. (1985). Początki Białegostoku i okolicznego osadnictwa. Studia i materiały do dziejów miasta Białegostoku, IV, 16-23. Białystok.

Wiśniewski, J. (1980). Zarys dziejów osadnictwa na Białostocczyźnie. Atlas gwar wschodniosłowiańskich Białostocczyzny, t. I. Wrocław.

Wolff, J. (1895). Kniaziowie litewsko-ruscy.

Voluminam Legum (1859). Petersburg.

Żychlińśki, T. (1896). Złota Księga Szlachty polskiej, XVIII. Poznań. 
ISSN 1508-7719

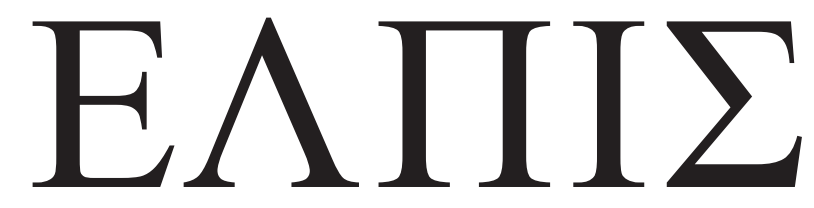

CZASOPISMO TEOLOGICZNE KATEDRY TEOLOGII PRAWOSŁAWNEJ UNIWERSYTETU W BIAŁYMSTOKU

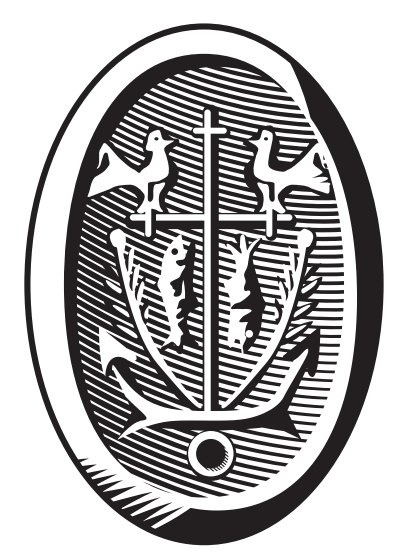

ADRES REDAKCJI

ul. Ludwika Zamenhofa 15, 15-435 Białystok, Polska tel. 85 745-77-80, e-mail: elpis@uwb.edu.pl www.elpis.uwb.edu.pl 